\title{
The genetic overlap of attention deficit hyperactivity disorder and autistic spectrum disorder
}

\author{
Arie J Stam \\ Patricia F Schothorst \\ Jacob AS Vorstman \\ Wouter G Staal \\ University Medical Center Utrecht \\ (UMC Utrecht), Utrecht, \\ The Netherlands
}

\begin{abstract}
Autistic spectrum disorders (ASD) and attention deficit hyperactivity disorder (ADHD) are classified as distinct disorders within the DSM-IV-TR (1994). The manual excludes simultaneous use of both diagnoses in case of overlap on a symptomatic level. However this does not always represent clinical observations and findings of previous studies. This review explores the genetic basis of the phenomenological overlap between ADHD and ASD. Based on an extensive review of twin-, linkage-, association studies, and reported structural genomic abnormalities associated with these disorders, we have identified seventeen regions on the human genome that can be related to both disorders. These regions of shared genetic association are: 2q35, 3p14, 4p16.1, 4p16.3, 5p15.31, 5p15.33, 7p12.3, 7p22, 7q21, 8q24.3, 14q12, 15q11-12, $16 \mathrm{p} 13,17 \mathrm{q} 11,18 \mathrm{q} 21-23,22 \mathrm{q} 11.2, \mathrm{Xp} 22.3$. The presented data are of interest for future genetic studies and appear to suggest the existence of a phenotype partition that may differ from the current classification of psychiatric disorders.
\end{abstract}

Keywords: ADHD, autism, genetic, overlap

\section{Introduction}

Attention deficit hyperactivity disorder (ADHD) is a common childhood psychiatric disorder, with a variety of symptoms and a worldwide prevalence between $8 \%-12 \%$ or around $2 \%$ when significant impairment is included within the diagnostic criteria. ${ }^{1,2}$ ADHD is one of the best-validated childhood diagnoses. ${ }^{3}$ Autistic spectrum disorders (ASD) are pervasive developmental disorders that originate in early childhood and include autistic disorder (AD), Rett syndrome, Asperger syndrome, and pervasive development disorders - not otherwise specified (PDD-NOS). ${ }^{4}$ The reported prevalence of ASD has increased over the past 20 years and current estimated prevalence figures range from 27.5 to 107.6 per $10,000 .^{5,6}$

The risk to develop ADHD and ASD is largely determined by genetic factors, as has been shown in several family and twin studies. On average, the genetic risk for ADHD is estimated to be $76 \%$ as can be deducted from twin studies from Europe, the United States, and Australia. ${ }^{7-13}$

For ASD, twin studies in autism have provided concordance rates between $36 \%-96 \%$ for monozygotic twins and $0 \%-30 \%$ for dizygotic twin pairs of the same sex. ${ }^{14}$ Based on these findings, it is estimated that the genetic risk for autism is over $90 \%$. It has also been suggested that twinning itself might be part of the etiology of ASD, but this has been contested. ${ }^{15}$

ADHD and ASD are traditionally considered distinct and the diagnosis of ADHD still belongs to the exclusionary criteria for ASD. ${ }^{16}$ However, cumulative evidence from behavioral studies, neurocognitive studies and genetic studies suggests an etiological overlap between ADHD and ASD. ${ }^{16-26}$ Both are early-onset psychiatric disorders 
placed within the realm of child- and adolescent psychiatry. ${ }^{4}$ A considerable amount of ADHD patients show problems in communication and social interaction as observed in ASD. ${ }^{23-25}$ In addition, autistic children often show high levels of impulsivity, inattention, and hyperactivity. ${ }^{16,20,21}$ It has been suggested by family and twin studies that these overlapping traits can be explained by common genetic influences. ${ }^{22-26}$

This review focuses on the overlap in genetic association of ADHD and ASD, in order to provide a stronger basis for understanding the shared biological processes which affect cognitive domains which may underlie both disorders. The aim of this study is to provide a clear overview of all genomic regions associated to ADHD or ASD, thereby identifying regions of shared genetic overlap between these disorders.

\section{Methods}

This review is based upon a literature survey within the PubMed database and Google Scholar search engine. First, the latest reviews about the genetics of autism and ADHD were selected for a broad orientation. Next, a systematic evaluation by using combinations of keywords including ADHD, Autis*, gene*, overlap, molecul*, etc. within these databases was performed. Studies were selected based on several criteria including diagnostic methods and a fixed statistical threshold with regard to linkage and association studies. With regard to ADHD, studies on the combined subtype, as well as all studies including patients with the inattentive or with the hyperactive subtype were included in this review. For ASD the studies which involved subjects diagnosed with autistic disorder, Asperger's disorder and PDD-NOS according to DSM-IV (TR) criteria were included. For linkage studies to be included in this review, a logarithm of odd (LOD) score of 2.2 (suggestive linkage) or higher was required. ${ }^{27}$ In order to minimize the risk of overinterpretation, linkage regions were conservatively defined as extending $10 \mathrm{~kb}$ at either side of the reported marker. Only the occurrence of other independent findings within this region was considered as possible overlap.

The significance threshold (corrected for multiple testing), reported in association studies was considered significant when $\mathrm{P}<0.05$, and reported $\mathrm{P}$-values between 0.05 and 0.10 were considered as suggestive. Only regions indicated by significant results were included in this review, however, a genomic region was also included when supported by suggestive results of two or more studies. Studies on cytogenetic abnormalities and case reports involving patients with cytogenetic abnormalities were only included if a validated checklist and/or a diagnosis according to DSM or ICD classification was described, as well as an interpretable annotation of the involved genomic region.

All overlapping linkage and cytogenetic regions meeting these criteria were considered as loci putatively containing risk genes for a common etiology between ADHD and ASD.

\section{Results}

The loci and genes found in both ASD and ADHD by the literature survey are represented below. Figure 1 provides a complete and schematic overview of all included studies. Table 1 describes the 17 regions of overlap including the boundaries and involved studies.

\section{Discussion}

This review provides an overview of a joint genetic basis for ASD and ADHD through association-, linkage-, and cytogenetic studies. Seventeen regions on the human genome can be related to both disorders including: $2 \mathrm{q} 35$, 3p14, 4p16.1, 4p16.3, 5p15.31, 5p15.33, 7p12.3, 7p22, 7q21, 8q24.3, 14q12, 15q11-12, 16p13, 17q11, 18q21-23, 22q11.2, Xp22.3. These regions reflect about $36 \%$ of the loci involved in ADHD, whereas they reflect about $14 \%$ of the regions related to ASD.

These findings suggest that at least some shared genetic risk factors exist between ADHD and ASD, which may have implications for our concepts of these disorders.

However, for an adequate interpretation of these findings it is important to bear in mind that several limitations exist in our evaluation of the literature.

First, it is possible that some studies with relevant information were missed during the literature search. For example, studies that do not find associations with the regions described in this review are possibly less likely to be submitted for publication, leading to a publication-based biased overview of associated regions.

Second, pragmatic decisions have been made regarding the representation of linkage studies. Unfortunately, no consensus exists about the precise distance around the linkage peak that should be considered important. Moreover, generally weak significance scores are found for both disorders. This can be explained by the genetic complexity of the disorders and the small sample sizes of certain studies. In order to minimize the risk of type 1 errors, we have opted for a fairly conservative definition of linkage ( $10 \mathrm{~kb}$ at either side of the reported marker) for the current analysis.

Third, it is quite possible that although loci for ASD and ADHD overlap, different genes within these overlap regions are related to each disorder. 

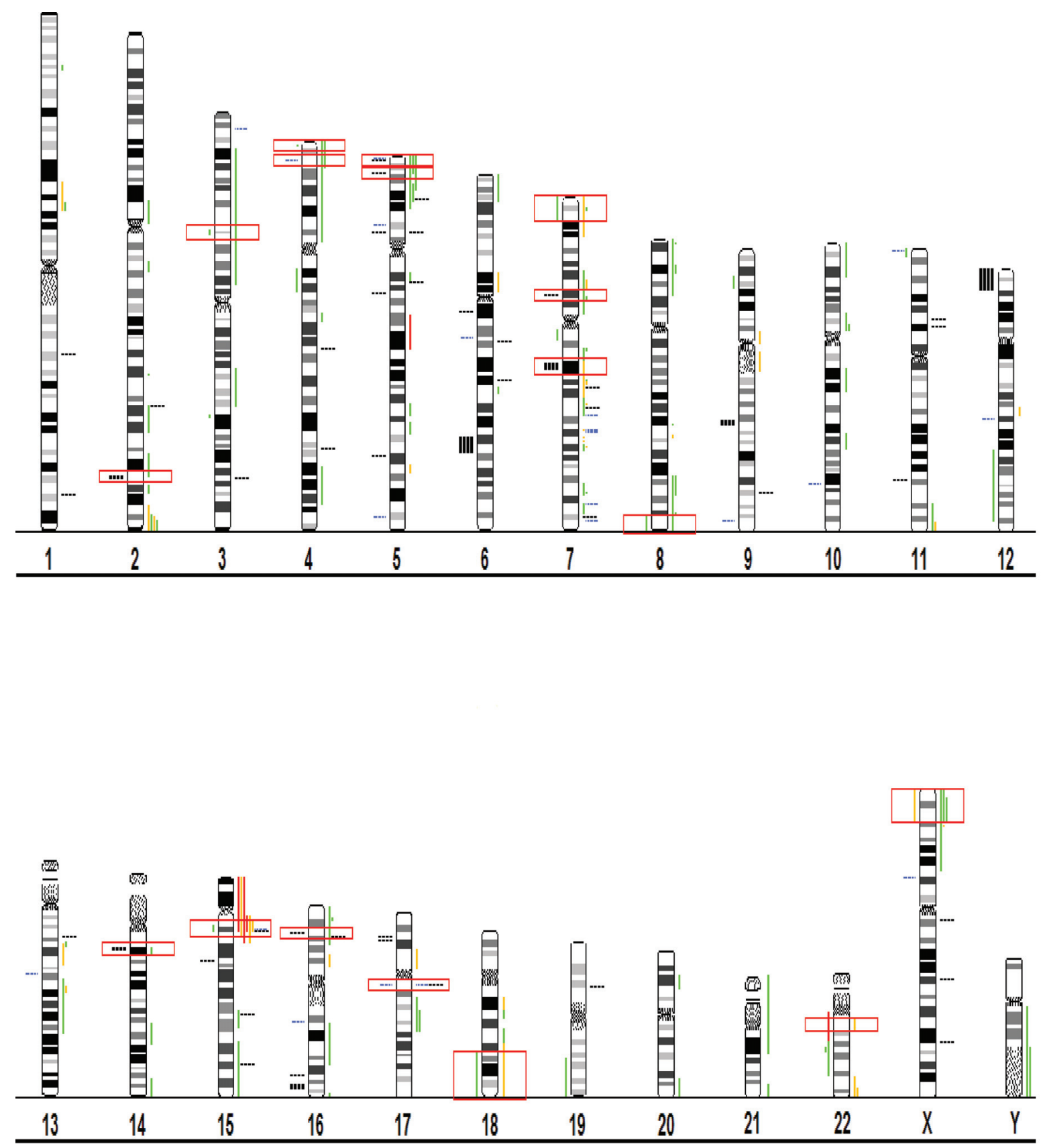

Figure I The genetic overlap of ADHD and ASD.

Notes: This figure shows 24 human chromosomes. On the left side of each chromosome the results of genetic studies on ADHD are provided. On the right side of each chromosome the genetic findings on ASD are given. Linkage studies are represented by black dotted horizontal lines. Association studies are indicated by blue dotted horizontal lines. Cytogenetic studies are vertical lines in the colors green, orange and red. A green line represents a region described by one study. An orange line represents a region described by two, three our four studies. A red line represents a region described by five or more studies. Regions containing overlap in genetic findings associated to both ASD and ADHD are accentuated by a red box surrounding the region of interest. All data included in this figure are exactly positioned. Further details can be found in Table I.

Abbreviations: ADHD, attention deficit hyperactivity disorder; ASD, autistic spectrum disorders.

Fourth, we have focused on positive association findings. This elicits the risk of type 1 errors, since the majority of reported loci show contradictory findings about putative association. This can be partly explained by different methods and sample sizes, as well as variety in ethnicity of the studied samples. We propose that the association with both ADHD and ASD could be considered as additional evidence in support of the involvement of a locus.

Despite these limitations, the results of our analysis suggest that shared genetic etiologies may exist for ADHD and ASD, which may have implications for our clinical concepts of the disorders and the existing diagnostic procedures. The results 
Table I Regions of overlap and involved studies

\begin{tabular}{|c|c|c|c|}
\hline Band & Region of overlap/involved gene & ADHD Studies & ASD Studies \\
\hline $2 q 35$ & $217.16-217.71 \mathrm{Mb}$ & 28 & 29 \\
\hline $3 \mathrm{p} / 4$ & $50.69-5 \mathrm{I} .40 \mathrm{Mb}$ & 30 & 31 \\
\hline $4 p 16.3$ & I.8-2.2 Mb & 32 & 33,34 \\
\hline $4 p 16.1$ & DRD5 & 35,36 & 33,34 \\
\hline $5 p \mid 5.33$ & I.44-I.50 Mb (SLC6A3) & $37-52$ & 53,54 \\
\hline $5 p \mid 5.31$ & 7.70-7.72 Mb & 55 & 53,54 \\
\hline $7 p 22$ & $0.00-7.20 \mathrm{Mb}$ & 56 & $57-59$ \\
\hline $7 p \mid 2.3$ & $49.35-49.37 \mathrm{Mb}$ & 18 & 60 \\
\hline $7 q 21$ & $77.95-8 \mathrm{I} .40 \mathrm{Mb}$ & 28 & 61,62 \\
\hline $8 q 24.3$ & I $40.0 \mathrm{Mb}-8$ qter & 56 & 63 \\
\hline $14 q 12$ & $24.30-24.98 \mathrm{Mb}$ & 28 & 64 \\
\hline $15 q \mid 1-12$ & 21.54-24.43 Mb (GABRB3) & 65 & $34,53,65-85$ \\
\hline $16 p \mid 3$ & $11.94-11.96 \mathrm{Mb}$ & $86-88$ & 89 \\
\hline$|7 q| 1$ & SLC6A4 (5HTT) & $90-94$ & $95-101$ \\
\hline I8q21-18 qter & $52.0 \mathrm{Mb}-18$ qter & 102 & 103,104 \\
\hline $22 q 11.2$ & 16.97-20.83 Mb & $105-111$ & $112-115$ \\
\hline Xp22.3 & $0.00-10.0 \mathrm{Mb}$ & $116-117$ & 118 \\
\hline
\end{tabular}

Notes: This table provides the information necessary to interpret the highlighted red boxes of Figure I. Within each band a particular region of overlap is given, obtained by the methods described previously.

Abbreviations: ADHD, attention deficit hyperactivity disorder; ASD, autistic spectrum disorders.

of this paper provide a biological argument for applying a less stringent nosology. In fact, the existing exclusionary criteria for both disorders within the DSM-IV should be reconsidered. Moreover, this paper provides the biological argument to allow a more pragmatic view regarding treatment of overlapping symptoms, which could otherwise be missed.

Several methodological advantages of this study strengthen this interpretation of data.

First of all, the study provides a complete overview of associated genomic regions of both disorders. This is relevant, because a substantial genetic influence for both disorders was described, with a higher genetic risk for ASD than for ADHD. Our search for shared genetic association between ASD and ADHD is motivated by the clinical overlap between both disorders and the findings from twin and family studies.

Second, this review provides the basis for a bottom-up approach in research on the overlap of ADHD and ASD. Seventeen putative loci relevant for a molecular explanation of the overlap between ADHD and autism have been described. These include: $2 \mathrm{q} 35,3 \mathrm{p} 14,4 \mathrm{p} 16.1,4 \mathrm{p} 16.3,5 \mathrm{p} 15.31,5 \mathrm{p} 15.33$, 7p12.3, 7p22, 7q21, 8q24.3, 14q12, 15q11-12, 16p13, 17q11, 18q21-23, 22q11.2, Xp22.3. Although the interpretation of the results may not be straightforward and further research is clearly necessary, our findings do appear to provide robust, albeit indirect evidence for at least some shared genetic overlap between ASD and ADHD. This notion is consistent with the findings of a recent twin study. ${ }^{22}$ The implicated regions of the current study may be of help when interpreting data from ongoing genome-wide association studies for ADHD and autism. Furthermore, these findings are in line with the emerging hypothesis that nosologically distinct psychiatric phenotypes, such as ADHD and ASD, or schizophrenia and bipolar disorder, may have shared biological etiologies. ${ }^{119}$

In conclusion, findings of our analysis are in support of shared genetic etiologies for ASD and ADHD. A pragmatic consequence of this finding may be that it provides some justification for a combined analysis of genetic association for ASD and ADHD. On a more conceptual level, our results suggest that the biology of ASD and ADHD does not seem to follow the boundaries laid out by our nosologic classification system.

\section{Disclosure}

No financial or other types of support have been granted or used.

\section{References}

1. Faraone SV, Sergeant J, Gillberg C, Biederman J. The worldwide prevalence of ADHD: Is it an American condition? World Psychiatry. 2003;2(2):104-113.

2. Lahey BB, Miller TL, Gordon RA, et al. Developmental epidemiology of the disruptive behavior disorders. In: Quay HC, Hogan AE, editors. Handbook of Disruptive Behavior Disorders. New York: Kluwer Acedemic/Plenum Publishers; 1999. p. 23-48. 
3. Faraone SV, Biederman J. Neurobiology of attention-deficit hyperactivity disorder. Soc Biol Psychiatry. 1998;44(10):951-958.

4. American Psychiatric Association (APA). Diagnostic and Statistical Manual of Mental Disorders: DSM-IV-TR, 4th ed. Washington DC: American Psychiatric Association; 2000.

5. Fombonne E. Zakarian R, Bennett A, Meng L, McLean-Heywood D. Pervasive developmental disorders in Montreal, Quebec, Canada: Prevalence and Links with Immunizations. Pediatrics. 2006;118(1): e139-e150.

6. Waterhouse L. Autism Overflows: Increasing prevalence and proliferating theories. Neuropsychol Rev. 2008;18(4):273-286.

7. Coolidge FL, Thede LL, Young SE. Heritability and the comorbidity of attention deficit hyperactivity disorder with behavioral disorders and executive function deficits: a preliminary investigation. Dev Neuropsychol. 2000;17(3):237-287.

8. Hudziak JJ, Rudiger LP, Neale MC, Heath AC, Todd RD. A twin study of inattentive, aggressive, and anxious/depressed behaviors. $J$ Am Acad Child Adolesc Psychiatry. 2000;39(4):469-476.

9. Martin N, Scourfield J, McGUffin P. Observer effects and heritability of childhood attention-deficit hyperactivity disorder symptoms. $\mathrm{Br} J$ Psychiatry. 2002;180:260-265.

10. Rietveld MJ, Hudziak JJ, Bartels M, van Beijsterveldt CE, Boomsma. Heritability of attention problems in children: cross-sectional results from a study of twins, age 3-12 years. Am JMed Genet B Neuropsychiatr Genet. 2003;117B(1):102-113.

11. Thapar A, Harrington R, Ross K, McGuffin P. Does the definition of ADHD affect heritability? J Am Acad Child Adolesc Psychiatry. 2000;39(12):1528-1536

12. Wilcutt EG, Penington BF, De Fries JC. Etiology of inattention and hyperactivity/impulsivity in a community sample of twins with learning difficulties. J Abnorm Child Psychol. 2000;28(2):149-159.

13. Faraone SV, Perlis RH, Doyle AE, et al. Molecular genetics of attention-deficit/hyperactivity disorder. Soc Biol Psychiatry. 2005;57 1313-1323.

14. Freitag CM. The genetics of autistic disorders and its clinical relevance: a review of the literature. Mol Psychiatry. 2007;12(1):2-22.

15. Hallmayer J, Glasson EJ, Bower C, et al. On the twin risk in autism. Am J Hum Genet. 2002;71(4):941-946.

16. Holtmann M, Bölte S, Pousta F. Attention deficit hyperactivity disorder symptoms in pervasive developmental disorders: association with autistic behavior domains and coexisting psychopathology. Psychopathology. 2007;40(3):172-177.

17. Smalley SL, Kustanovich V, Minassian SL, et al. Genetic linkage of attention-deficit/hyperactivity disorder on chromosome 16p13, in a region implicated in autism. Am J Hum Genet. 2002;71(4):959-963.

18. Bakker SC, van der Meulen EM, Buitelaar JK, et al. A whole-genome scan in 164 Dutch sib pairs with attention-deficit/hyperactivity disorder: suggestive evidence for linkage on chromosome 7p and 15q. Am J Hum Genet. 2003;72(5):1251-1260.

19. Yoshida $Y$, Uchiyama $T$. The clinical necessity for assessing attention deficit/hyperactivity disorder (AD/HD) symptoms in children with high-functioning Pervasive Developmental Disorder (PDD). Eur Child Adolesc Psychiatry. 2004;13(5):307-314.

20. Lee DO, Ousley OY. Attention-deficit hyperactivity disorder symptoms in a clinical sample of children and adolescents with pervasive developmental disorders. J Child Adolesc Psychopharmacol. 2006;16(6):737-746.

21. Leyfer OT, Folstein SE, Bacalman S, et al. Comorbid psychiatric disorders in children with autism: interview development and rates of disorders. J Autism Dev Disord. 2006;36(7):849-861.

22. Ronald A, Simonoff E, Kuntsi J, Asherson P, Plomin R. Evidence for overlapping genetic influences on autistic and ADHD behaviours in a community twin sample. $J$ Child Psychol Psychiatry. 2008;49(5): $535-542$.

23. Reiersen AM, Constantino JN, Todd RD. Co-occurrence of motor problems and autistic symptoms in attention-deficit/hyperactivity disorder. J Am Acad Child Adolesc Psychiatry. 2008;47(6):662-672.
24. Mulligan A, Anney RJL, O'Regan M, et al. Autism symptoms in attention-deficit//hyperactivity disorder: a familiar trait which correlates with conduct, oppositional defiant, language and motor disorders. J Autism Dev Disord. Epub 2008 Jul 19.

25. Reiersen AM, Constatino JN, Volke HE, Todd RD. Autistic traits in a population-based ADHD twin sample. J Child Psychol Psychiatry. 2007;48(5):464-472.

26. Reiersen AM, Constantino JN, Grimmer M, Martin NG, Todd RD. Evidence for shared genetic influences on self-reported ADHD and autistic symptoms in young adult Autralian twins. Twin Res Hum Genet. 2008;11(6):579-585.

27. Lander E, Kruglyak L. Genetic dissection of complex traits: guidelines for interpreting and reporting linkage results. Nat Genet. 1995;11(3): 241-247.

28. Romanos M, Freitag C, Jacob C, et al. Genome-wide linkage analysis of ADHD using high-density SNP arrays: nocel loci at 5q31.1 and 14q12. Mol Psychiatry. 2008;13(5):522-530.

29. Pescucci C, Meloni I, Bruttini M, et al. Chromosome 2 deletion encompassing the MAP2 gene in a patient with autism and Rett-like features. Clin Genet. 2003;64(6):497-501.

30. de Silva MG, Elliott K, Dahl HH, et al. Disruption of a novel member of a sodium/hydrogen exchanger family and DOCK3 is associated with an attention deficit hyperactivity disorder-like phenotype. J Med Genet. 2003;40(10):733-740.

31. Mariner R, Jackson AW 3rd, Levitas A, et al. Autism, mental retardation, and chromosomal abnormalities. J Autism Dev Disord. 1986;16(4):425-440.

32. Rauch A, Schellmoser S, Kraus C, et al. First known microdeletion within the Wolf-Hirschhorn syndrome critical region refines genotypephenotype correlation. Am J Med Genet. 2001;99(4):338-342.

33. Medne L, Russel K, Ming J, et al. Subtelomeric FISH analysis in 108 autistic patients as adjunct to chromosome analysis and fragile $\mathrm{X}$ testing. ASHG. 2003;(847).

34. Lucchese $\mathrm{S}$, Takahashi $\mathrm{N}$, Miles J. Is autism caused by numerous genetic and cytogenetic syndromes? ASHG. 2003;(589).

35. Lowe N, Kirley A, Hawi Z, et al. Joint anakysis of the DRD5 marker concludes association with attention-deficit/hyperactivity disorder confined to the predominantly inattentive and combined subtypes. $\mathrm{Am}$ J Hum Genet. 2004;74:348-356.

36. Squassina A, Lanktree M, De Luca V, et al. Investigation of the dopamine D5 receptor gene (DRD5) in adult attention deficit hyperactivity disorder. Neurosci Lett. 2008;432(1):50-53.

37. Friedel S, Saar K, Sauer S, et al. Association and linkage of allelic variants of the dopamine transporter gene in ADHD. Mol Psychiatry. 2007;12:923-33.

38. Cook EH Jr, Stein MA, Krasowski MD, et al. Association of attentiondeficit disorder and the dopamine transporter gene. Am J Hum Genet. 1995;56(4):993-998.

39. Gill M, Daly G, Heron S, Hawi Z, Fitzgerald M. Confirmation of association between attention defecit hyperactivity disorder and a dopamine transporter polymorphism. Mol Psychiatry. 1997;2(4):311-313.

40. Qian Q, Wang Y, Zhou R, Yang L, Faraone SV. Family-based and case-control association studies of DRD4 and DAT1 polymorphisms in Chinese attention deficit hyperactivity disorder patients suggests long repeats contribute to genetic risk for the disorder. Am J Med Genet B Neuropsuchiatr Genet. 2004;128B(1):84-89.

41. Todd RD, Huang H, Smalley SL, et al. Collaboratuve analysis of DRD4 and DAT genotypes in population-defined ADHD subtypes. $J$ Child Psychol Psychiatry. 2005;46(10):1067-1073.

42. Feng Y, Wigg KG, Makkar R, et al. Sequence variation in the 3'-untranslated region of the dopamine transporter gene and attention-defecit hyperactivity disorder (ADHD). Am J Med Genet B Neuropsychiatr Genet. 2005;139B(1):1-6.

43. Cornish KM, Manly T, Savage R, et al. Association of the dopamine transporter (DAT1) 10/10-repeat genotype with ADHD symptoms and response inhibition in a general population sample. Mol Psychiatry. 2005;10(7):686-698. 
44. Brookes $\mathrm{K}, \mathrm{Xu} \mathrm{X}$, Chen $\mathrm{W}$, et al. The analysis of 51 genes in DSM-IV combined type attention deficit hyperactivity disorder: association signals in DRD4, DAT1 and 16 other genes. Mol Psychiatry. 2006;11(10):934-953.

45. Ohadi M, Shirazi E, Tehranidoosti M, et al. Attention-deficit/ hyperactivity disorder (ADHD) association with the DAT1 core promoter-67 T allele. Brain Res. 2006;1101(1):1-4.

46. Brookes KJ, Mill J, Guindalani C, et al. A common haplotype of the dopamine transporter gene associated with attention-deficit/hyperactivity disorder and interacting with maternal use of alcohol during pregnancy. Arch Gen Psychiatry. 2006;63(1):74-81.

47. Kim JW, Kim BN, Cho SC. The dopamine transporter gene and the impulsivity phenotype in attention deficit hyperactivity disorder: a case-control association study in a Korean sample. J Psychiatr Res. 2006;40(8):730-737.

48. Quellet-Morin I, Wigg KG, Feng Y, et al. Association of the dopamine transporter gene and ADHD symptoms in a Canadian population-based sample of same-age twins. Am J Med Genet B Neuropsychiatr Genet. Epub 2007 Dec 28.

49. Laucht M, Skowronek MH, Becker K, et al. Interacting effects of the dopamine transporter gene and psychosocial adversity on attentiondeficit/hyperactivity disorder symptoms among 15-year-olds from a highrisk community sample. Arch Gen Psychiatry. 2007;64(5):585-590.

50. Asherson P, Brookes K, Franke B, et al. Confirmation that a specific haplotype of the dopamine transporter gene is associated with combinedtype ADHD. Am J Psychiatry. 2007;164(4):674-677.

51. Lee SS, Lahey BB, Waldman I, et al. Association of dopamine transporter genotype with disruptive behavior disorders in an eightyear longitudinal study of children and adolescents. Am J Med Genet B Neuropsychiatr Genet. 2007;144B(3):310-317.

52. Genro JP, Zeni C, Polanczyk GV, et al. A promoter polymorphism $(-839 \mathrm{C}>\mathrm{T})$ at the dopamine transporter gene is associated with attention deficit/hyperactivity disorder in Brazilian children. Am J Med Genet B Neuropsychiatr Genet. 2007;144B(2):215-219.

53. Cantú ES, Stone JW, Wing AA, Langee HR, Williams CA. Cytogenetic survey for autistic fragile $\mathrm{X}$ carriers in a mental retardation center. $\mathrm{Am}$ J Ment Retard. 1990;94(4):442-447.

54. Vostanis P, Harrington R, Prendergast M, Farndon P. Case reports of autism with interstitial deletion of chromosome 17 (p11.2 p11.2) and monosomy of chromosome 5 (5 pter->5p15.3). Psychiatr Genet. 1994;4(2):109-111.

55. Hebebrand J, Dempfle A, Saar K, et al. A genome-wide scan for attention-deficit/hyperactivity disorder in 155 German sib-pairs. Mol Psychiatry. 2006;11(2):196-205.

56. Menabbawy KA, Gerzawy AE, Ezzat A, Mottawie H. Developmental, behavioral and genetic factors in correlation with attention deficit hyperactivity disorder in Egyptian children. J Med Sci. 2006;6(4):569-576.

57. Herder GA. Infantile autism among children in the county of Nordland. Prevalence and etiology. Tidsskr Nor Laegeforen. 1993;113(18): 2247-2249.

58. Gillberg C. Chromosomal disorders and autism. J Autism Dev Disord. 1998;28(5):415-425.

59. Yu CE, Dawson G, Munson J, et al. Presence of large deletions in kindreds with autism. Am J Hum Genet. 2002;71(1):100-115.

60. Wolpert CM, Donnelly SL, Cuccaro ML, et al. De novo partial duplication of chromosome $7 \mathrm{p}$ in a male with autistic disorder. $\mathrm{Am} \mathrm{J}$ Med Genet. 2001;105(3):222-225.

61. Lauritsen M, Mors O, Mortensen PB, Ewald H. Infantile autism and associated autosomal chromosome abnormalities: a register-based study and a literature survey. J Child Psychol Psychiatry. 1999;40(3):335-345.

62. Bugge M, Bruun-Petersen G, Brondum-Nielsen K, et al. Disease associated balanced chromosome rearrangements: a resource for large scale genotype-phenotype delineation in man. J Med Genet. 2000;37(11):858-865.

63. Weidmer-Mikhail E, Sheldon S, Ghaziuddin M. Chromosomes in autism and related pervasive developmental disorders: a cytogenetic study. J Intellect Disabil Res. 1998;42(Pt 1):8-12.
64. Castermans D, Wilquet V, Parthoens, et al. The neurobeachin gene is disrupted by a translocation in a patient with idiopathic autism. J Med Genet. 2003;40(5):352-356.

65. Thomas JA, Johnson J, Peterson Kraai TL, et al. Genetic and clinical characterization of patients with an interstitial duplication 15q11-q13, emphasizing behavioral phenotype and response to treatment. $\mathrm{Am} \mathrm{J}$ Med Genet A. 2003;119A(2):111-120.

66. Schroer RJ, Phelan MC, Michaelis RC, et al. Autism and maternally derived aberrations of chromosome 15q. Am JMed Genet. 1998;76(4): 327-336.

67. Borgatti R, Piccinelli P, Passoni, et al. Relationship between clinical and genetic features in "inverted duplicated chromosome 15" patients. Pediatr Neurol. 2001;24(2):111-116.

68. Estecio MRH, Fett-Conte AC, Varella-Garcia M, Fridman C, Silva AE. Molecular and cytogenetic analyses on Brazilian youths with pervasive developmental disorders. J Autism Dev Disord. 2002;32(1):35-41.

69. Silva AE, Veyego-Lourenço SA, Fett-Conte AC, Goloni-Bertollo EM, Verella-Garcia M. Tetrasomy 15q11-q13 identified by fluorescence in situ hybridization in a patient with autistic disorder. Arq Neuropsiquiatr. 2002;60(2A):290-294

70. Filipek PA, Juranek J, Smith M, et al. Mitochondrial dysfunction in autistic patients with $15 \mathrm{q}$ inverted duplication. Ann Neurol. 2003;53(6):801-804.

71. Simic M, Turk J. Autistic spectrum disorder associated with partial duplication of chromosome 15; three case reports. Eur Child Adolesc Psychiatry. 2004;13(6):389-393.

72. Wolpert CM, Menold MM, Bass MP, et al. Three probands with autistic disorder and isodicentric chromosome 15. Am J Med Genet. 2000;96(3):365-372.

73. Gillberg C, Steffenburg S, Wahlstrom J, et al. Autism associated with marker chromosome. J Am Acad Child Adolesc Psychiatry. 1991;30(3):489-494.

74. Hotopf M, Bolton P. A case of autism associated with partial tetrasomy 15 . J Autism Dev Disord. 1995;25(1):41-49.

75. Konstantareas MM, Homatidis S. Chromosomal abnormalities in a series of children with autistic disorder. J Autism Dev Disord. 1999;29(4):275-285.

76. Rineer S, Finucane B, Simon EW. Autistic symptoms among children and young adults with isodicentric chromosome 15. Am J Med Genet. 1998;81(5):428-433.

77. Kwasnicka D, Roberts W, Li M, Rusell S, Choufani S, Scherer S. Characterization of maternally derived aberration of chromosome $15 \mathrm{q}$ in a patient with autism. $A S H G$. 2004;(962).

78. Steffenburg S, Gillberg CL, Steffenburg U, Kyllerman M. Autism in Angelman syndrome: a population-based study. Pediatr Neurol. 1996;14(2):131-136.

79. Sabry MA, Farag TI. Chromosome 15q11-13 region and the autistic disorder. J Intellect Disabil Res. 1998;42(Pt 3):259.

80. Bolton PF, Dennis NR, Browne CE, et al. The phenotypic manifestations of interstitial duplications of proximal $15 \mathrm{q}$ with special reference to the autistic spectrum disorders. Am J Med Genet. 2001;105(8):675-685.

81. Keller K, Williams C, Wharton P, et al. Routine cytogenetic and FISH studies for $17 \mathrm{p} 11 / 15 \mathrm{q} 11$ duplications and subtelomeric rearrangement studies in children with autism spectrum disorders. Am J Med Genet. 2003;117A(2):105-111.

82. Kashork CD, Stockton DW, SahooT, Bercovich D, Shaffer LG, Beaudet AL. Identification of Chromosomal Abnormalities and Susceptibility Loci on Chromosome 15q in Autism Families. ASHG. 2003;(1793).

83. Cook EH Jr, Lindgren V, Leventhal BL, et al. Autism or atypical autism in maternally but not paternally derived proximal $15 \mathrm{q}$ duplication. $\mathrm{Am}$ J Hum Genet. 1997;60(4):928-934.

84. Gurrieri F, Battaglia A, Torrisi L, et al. Pervasive developmental disorder and epilepsy due to maternally derived duplication of 15q11-q13. Neurology. 1999;52(8):1694-1697.

85. Smith M, Hanouni M, Spence MA, Gargus JJ, LeRoux J. Paternally derived 15q12-q13 duplication associated with Autism Spectrum Disorder. $A S H G$. 2004;(1015/W). 
86. Smalley SL, Kustanovich V, Minassian SL, et al. Genetic linkage of attention-deficit/hyperactivity disorder on chromosome 16p13, in a region implicated in autism. Am J Hum Genet. 2002;71(4):959-963.

87. Ogdie MN, Macphie IL, Minassian SL, et al. A genomewide scan for attention-deficit/hyperactivity disorder in an extended sample: suggestive linkage on 17p11. Am J Hum Genet. 2003;72(5):1268-1279.

88. Ogdie MN, Fisher SE, Yang M, et al. Attention deficit hyperactivity disorder: fine mapping supports linkage to $5 \mathrm{p} 13,6 \mathrm{q} 12,16 \mathrm{p} 13$ and 17p11. Am J Hum Genet. 2004;75(4):661-668.

89. Hebebrand J, Martin M, Körner J, et al. Partial trisomy 16p in an adolescent with autistic disorder and Tourette's syndrome. Am J Med Genet. 1994;54(3):268-270.

90. Manor I, Eisenberg J, Tyano S, et al. Family-based association study of the serotonin transporter promoter region polymorphism (5-HTTLPR) in attention deficit hyperactivity disorder. $\mathrm{Am} \mathrm{J} \mathrm{Med}$ Genet. 2001;105(1):91-95.

91. Kent L, Doerry U, Hardy E, et al. Evidence that variation at the serotonin transporter gene influences susceptibility to attention deficit hyperactivity disorder (ADHD): analysis and pooled analysis. Mol Psychiatry. 2002;7(8):908-912.

92. Cadoret RJ, Langbehn D, Caspers K, et al. Associations of the serotonin transporter promoter polymorphism with aggressivity, attention deficit, and conduct disorder in an adoptee population. Compr Psychiatry. 2003;44(2):88-101.

93. Kim SJ, Badner J, Cheon KA, et al. Family-based associated study of the serotonin transporter gene polymorphism in Korean ADHD trios. Am J Med Genet B Neuropsychiatr Genet. 2005;139B(1):14-18.

94. Banerjee E, Sinha S, Chatterjee A, Gangopadhyay PK, Singh M, Nandagopal K. A family-based study of Indian subjects from Kolkata reveals allelic association of the serotonin transporter intron-2 (STin2) polymorphism and attention-deficit-hyperactivity disorder (ADHD). Am J Med Genet B Neuropsychiatr Genet. 2006;141B(4):361-366.

95. Cook EH Jr, Courchesne R, Lord C, et al. Evidence of linkage between the serotonin transporter and autistic disorder. Mol Psychiatry. 1997;2(3):247-250.

96. Klauck SM, Poustka F, Benner A, Lesch A, Lesch KP, Poustka A. Serotonin transporter (5-HTT) gene variants associated with autism? Hum Mol Genet. 1997;6(13):2233-2238.

97. Yirmiya N, Pilowsky T, Nemanov L, et al. Evidence for an association with the serotonin transporter promoter region polymorphism and autism. Am J Med Genet. 2001;105(4):381-386.

98. Kim SJ, Cox N, Courchesne R, et al. Transmission disequilibrium mapping at the serotonin transporter gene (SLC6A4) region in autistic disorder. Mol Psychiatry. 2002;7(3):278-288.

99. Conroy J, Meally E, Kearney G, Fitzgerald M, Gill M, Gallagher L. Serotonin transporter gene and autism: a haplotype analysis in an Irish autistic population. Mol Psychiatry. 2004;9(6):587-593.

100. Sutcliffe JS, Delahanty RJ, Prasad HC, et al. Allelic heterogeneity at the serotonin transporter locus (SLC6A4) confers susceptibility to autism and rigid-compulsive behaviors. Am J Hum Genet. 2005;77(2):265-279.

101. Cho IH, Yoo HJ, Park M, Lee YS, Kim SA. Family-based association study of 5-HTTLPR and the 5-HT2A receptor gene polymorphisms with autism spectrum disorder in Korean trios. Brain Res. 2007; 1139:34-41.

102. Zannolli R, Pierluigi M, Pucci L, et al. 18q-syndrome and ectodermal dysplasia syndrome: description of a child and his family. Am J Med Genet A. 2003;116(2):192-199.
103. Seshadri K, Wallerstein R, Burack.18q- chromosomal abnormality in a phenotypically normal 2 1/2-year-old male with autism. Dev Med Child Neurol. 1992;34(11):1005-1009.

104. Mahr RN, Moberg PJ, Overhauser J, et al. Neuropsychiatry of 18q- syndrome. Am J Med Genet. 1996;67(2):172-178.

105. Niklasson L, Rasmussen P, Oskarsdóttir S, Gillberg C. Chromosome 22q11 deletion syndrome (CATCH 22): neuropsychiatric and neuropsychological aspects. Dev Med Child Neurol. 2002;44(1):44-50.

106. Gothelf D, Presburger G, Levy D, et al. Genetic, developmental, and physical factors associated with attention deficit hyperactivity disorder in patients with velocardiofacial syndrome. Am J Med Genet B Neuropsychiatr Genet. 2004;126B(1):116-121.

107. Antshel KM, Fremont W, Roizen NJ, Shprintzen R, Higgins AM, Dhamoon A, Kates WR. ADHD, major depressive disorder, and simple phobias are prevalent psychiatric conditions in youth with velocardofacial syndrome. J Am Acad Child Adolesc Psychiatry. 2006;45(5):596-603.

108. Lajiness-O'Neill R, Beaulieu I, Asamoah A, et al. The neuropsychological phenotype of velocardiofacial syndrome (VCFS): relationship to psychopathology. Arch Clin Neuropsychol. 2006;21(2):175-184.

109. Zagursky K, Weller RA, Jessani N, Abbas J, Weller EB. Prevalence of ADHD in children with velocardiofacial syndrome: a preliminary report. Curr Psychiatry Rep. 2006;8(2):102-107

110. Arnold PD, Siegel-Bartelt J, Cytrynbaum C, Teshima I, Schachar R. Velo-cardiofacial syndrome: Implications of microdeletion 22q11 for schizophrenia and mood disorders. Am J Med Genet. 2001;105(4): 354-362

111. Papolos DF, Faedda GL, Veit S, et al. Bipolar spectrum disorders in patients diagnosed with velo-cardio-facial syndrome: does a hemizyggous deletion of chromosome 22q11 result in bipolar affective disorder? Am J Psychiatry. 1996;153(12):1541-1547.

112. Chudley AE, Gutierrez E, Jocelyn LJ, Chodirker BN. Outcomes of genetic evaluation in children with pervasive developmental disorder. J Dev Behav Pediatr. 1998;19(5):321-325.

113. Eliez S, Palacio-Espasa F, Spira A, et al. Young children with VeloCardio-Facial syndrome (CATCH-22). Psychological and language phenotypes. Eur Child Adolesc Psychiatry. 2000;9(2):109-114.

114. Niklasson L, Rasmussen P, Oskarsdottir S, Gillberg C. Neuropsychiatric disorders in the 22q11 deletion syndrome. Genet Med. 2001; 3(1):79-84.

115. Roubertie A, Semprino M, Chaze AM, et al. Neurological presentation of three patients with 22q11 deletion (CATCH 22 syndrome). Brain Dev. 2001;23(8):810-814.

116. Lonardo F, Parenti G, Luquetti DV, et al. Contiguous gene syndrome due to an interstitial deletion in Xp22.3 in a boy with ichthyosis, chondrodysplacia punctata, mental retardation and ADHD. Eur J Med Genet. 2007;50(4):301-308.

117. Boycott KM, Parslow MI, Ross JL, Miller IP, Bech-Hansen NT, MacLeod PM. A familial contiguous gene deletion syndrome at Xp22.3 characterized by severe learning disabilities and ADHD. Am J Med Genet A. 2003;122(2):139-147

118. Thomas NS, Sharp AJ, Browne CE, Skuse D, Hardie C, Dennis NR. $\mathrm{Xp}$ deletions associated with autism in three females. Hum Genet. 1999;104(1):43-48.

119. Craddock N, O'Donovan MC, Owen MJ. Genes for schizophrenia and bipolar disorder? Implications for psychiatric nosology. Schizophr Bull. 2006;32(1):9-16. 
